\title{
Exchange Rate Pass-Through and the Relative Concentration of German and Japanese Manufacturing Industries
}

\author{
Eric Fisher \\ Cornell University, Ithaca, NY 14853-7601, USA
}

\begin{abstract}
This note examines the rank correlation of export price markups and industrial concentration in German and Japanese manufactures in 1984 and 1986. It gives the most current measures of Japanese manufacturing concentration available in English.
\end{abstract}

\section{INTRODUCTION}

The purpose of this note is twofold. First, it presents current data on industrial concentration in Japanese and German manufactures; some of these data have not been readily available in English sources. Second, it conducts a simple non-parametric test of the hypothesis that Japanese and German manufacturing exporters priced their products strategically in taking advantage of exchange rate movements in 1984 and 1986. It shows that export price markups were significantly correlated with industrial concentration in Japan in 1984, the most recent year during which the yen depreciated against the dollar. Export markups were weakly correlated with concentration in the Gennan industries in the same year. There was little rank correlation between export price markdowns and industry concentration in either country during 1986, the first year of these currencies' current appreciations against the dollar. 
In recent years, there has been a growing theoretical literature on exchange rate pass-through.

Dornbusch (1987), Baldwin (1988), and Fisher (1989) have presented theoretical models of the effects of exchange rates on oligopoly pricing. These models demonstrate that international oligopolistic firms absorb some of the effects of exchange rate changes through changing profit margins. Dornbusch analyzed foreign and domestic firms producing for a segmented domestic market; he noticed that a Cournot model of oligopoly implied that there would be little exchange rate pass-through when there were a small number of world firms, most of whom were domestic. Although Dornbusch presented some aggregate data on exchange rate pass-through in the United States, he did not test this hypothesis about industry concentration directly. Using a Bertrand model, Fisher emphasized that firms set prices based upon expectations of exchange rate movements, and he extended Dornbusch's result to the case where home and foreign markets were not segmented. Fisher, too, did not test this hypothesis directly.

This note presents a simple and novel test of one of the primary implications of this theoretical work. This test is non-parametric; hence it does not depend on any specific functional forms describing the multi-variate distribution of oligopolistic prices and exchange rates. In particular, it uses the Spearman statistic to test whether the rank correlation between industry concentration and export price markup exhibits the following property.

Hypothesis. If there is an expected depreciation (appreciation), then producers in a concentrated industry will tend to raise (lower) export price markups more than producers in a competitive industry ${ }^{1 .}$

The tests show that here is weak evidence to support this hypothesis during the last year of the yen's and mark's depreciations, but the evidence is mixed during the first year of these currencies' current appreciations.

${ }^{1}$ For a formal statement of this theorem within the framework of a oligopolistic pricing model, see Fisher (1989, Theorem 3). 
There have been several empirical studies of exchange rate pass-through that have used dis-aggregated industry data, but none has tested this hypothesis in a simple and direct way. Using time series analysis, Dunn (1970) examined changes in the Canadian prices of window glass, gasoline, crude oil, coal, rollingmill products, and copper sampled at six-month intervals between 1950 and 1962. Mann (1986) studied nine export price indices and seven import price indices for American manufacturing industries between 1977 and 1985; she showed that exporters to the United States markets seemed to be increasing their profit margins as their currencies depreciated, whereas exporters within the United States did not seem to be decreasing their profit margins as the dollar appreciated. Using pooled cross-section and time series data, Feinberg (1986) examined the relationship between industry concentration and exchange rates in oligopolistic German industries between 1977 and 1983. He found that increased industry concentration had a slight effect on the manner in which changes in sector-specific real exchange rates were reflected in dis-aggregated price indices ${ }^{2}$.

Odagiri and Yamashita (1987) did not discuss exchange rate pass-through, but they did analyze price markups and the industry-specific effects of business cycles in a wide cross-section of Japanese industries between 1958 and 1982. They examined whether concentrated industries exhibited higher markups of prices above costs during recessions, but they were unable to find strong evidence to by Japan's Ministry of International Trade and Industry. Our note constructs its own measures of corroborate this hypothesis. Odagiri and Yamashita used 1971 concentration ratios that were published industrial concentration ratios for nine Japanese manufacturing industries; these measures are much more current than any others and they should be of interest to economists interested in international trade and Japanese industrial organization.

${ }^{2}$ Feinberg used the HerfindaW index as a measure of concentration. He did not include this index directly in any of his reported regressions; he used instead an interaction term that involved multiplying the Herfindahl index with a sector-specific exchange rate. 


\section{THE DATA AND THE RANK CORRELATION TESTS}

In this section, we present evidence on the relationship between industry concentration and exchange rate pass-through during 1984 and 1986 . These are of course both periods during which the major currencies were floating, and the first was a period of strong yen and mark depreciation against the dollar, while the second was one of strong yen and mark appreciation. We did not use data from 1985 because it was a year of changing expectations about the strength of the yen and mark. Under the assumption that the cross-section of industries surveyed faced the same average degree of international competition, the theoretical analysis in Dornbusch (1987) and Fisher (1989) makes 1:he positive prediction that pass-through will be higher in those Japanese and German indus1:ries which were relatively concentrated.

It is unfortunately extremely difficult to get a current measure of concentration in a cross-spectrum of Japanese industries. There is some work on industrial organization in Japan by Caves and Uekusa (1976), but they rely on concentration ratios collected by the Fair Trade Commission of Japan given in Niho no sangyo shuchu [Industrial Concentration in Japan 1963-1966] (1973). Those ratios are dated, and they give only the historical evolution of concentration within selected industries, not concentration across a sample of industries. In order to construct measures of concentration across industries, we used the Japan Statistical Yearbook (1983). The chapter entitled Business Operations gives summary aggregate financial data for principal enterprises in a cross-section of industries; a principal enterprise is either a company with a capitalization of at least one billion yen or a company which is considered a 'leading enterprise' in its industry. In 1981, there were a total of 342 such companies in the nine manufacturing industries in our sample. These data are no1: given on a firm-by-firm basis but are presented as a total for all the principal enterprises in an industry. This chapter also gives total sales figures for these 
different manufacturing industries. These sales figures were used to calculate a rough measure of industry concentration in 1981, and they are reported in the first column of table 1.

It is of course almost impossible to get data on individual transaction prices, but the Research and Statistics Department of the Bank of Japan does provide dis-aggregated wholesale price indices in the series Price Indices Monthly. These indices are dis-aggregated into ten different manufacturing subsectors, and they are further dis-aggregated in each sub-sector into average prices for exports, imports, and goods produced for domestic demand. The manufacturing sub-sectors correspond serendipitously to those defined in the Japan Statistical Yearbook, and nine of the universe of ten were chosen for table 1. The petroleum industry was excluded because there is only one petroleum product exported from Japan, and it seems to be priced in dollars, not yen.

The industries are presented in order of increasing concentration. The second column gives the percentage difference between the change in industries' export prices and domestic prices during 1984, and the third column gives the analogous number for 1986 . We use the difference between export prices and domestic prices in order to control for the effect that exchange rate movements had on costs, which was explicitly not a part of the model presented in Fisher (1988). First, it is reassuring that export prices rose more rapidly than domestic prices when the yen was depreciating may he and fell more rapidly when the yen was appreciating; this is of course one of the positive implications of the theory of exchange rate pass-through. Second, the Spearman statistic for the rank correlation between passthrough and industry concentration is significant at the $90 \%$ confidence level for 1984 , but it is not significant for $1986^{3}$. The small decrease in the export prices of transport equipment contributes to the rejection of a rank correlation in 1986. Perhaps the 'voluntary' export restraints on automobile exports to the United States have sufficiently cartelized the international industry so that Japanese firms have not

\footnotetext{
${ }^{3}$ See Bickel and Doksum (1977, table VIII) for this critical value.
} 


\section{Table 1}

Export price markups and industrial concentration in Japanese manufacturing industries. ${ }^{a}$

Manufacturing industry

Concentration

(1)

22.7

23.2

24.8

26.0

37.3

43.6

46.1

59.6

76.6

Transport equipment

36.6
1984

(2)

1.6

1.1

4.9

$-1.4$

1.6

0.1

9.1

5.2

4.5

${ }^{\circ}$ All D1.uubers are percents. Column (1) measures the ratio of sales by principal enterprises to total industry sales in 1981. Column (2) measures the difference between the change in export prices and domestic prices for each industry during the twelve months ending in December 1984. Column (3) is the analogous measure for the twelve months ending in December 1986. The sources are described in the text.

had to cut export prices significantly as the yen has appreciated.

Industry concentration ratios for Germany are much more readily available. The Monopolkom mission publishes statistics on concentration in a wide cross-section of industries about once every ten years.

The rankings given in table 2 were drawn from Mehr Wettbewerb ist Möglich (1976), published subsequent to the Hauptgutachten of $1973 / 1975$. Table 1.3 of this book publishes ratios of sales by the largest three firms to total industry sales for 33 manufacturing industries; these statistics were calculated by a special census done by the Statistisches Bundesamt in 1973. The Statistisches 
Bundesamt also publishes monthly price indices which are dis-aggregated by the same industry groupings for 29 of these industries. It publishes two separate series: one for domestic producer prices and one for import and export prices. We restrict our attention to the same nine industries as were presented for Japan, but the results for all 29 industries are not qualitatively different from those presented in table 2.

Table 2

Export price markups and industrial concentration in German manufacturing industries. ${ }^{a}$

Manufacturing industry

Concentration

1984

1986

(1)

(2)

(3)

Textile products

4.0

$-0.3$

1.3

Processed foodstuffs

1.7

0.5

Ceramic, stone, and clay products

7.3

0.8

$-1.1$

Machine tools

9.4

0.5

$-2.5$

Nonferrous metal products

26.0

0.0

11.0

Chemicals and allied products

27.5

0.6

7.2

Electrical machinery, equipment, and supplies

30.8

1.3

$-1.2$

Iron and steel

34.7

1.2

8.1

Transport equipment

53.0

0.4

$-2.4$

${ }^{0}$ All numbers are percents. Column (1) measures the ratio of sales by the three largest enterprises to total industry sales in 1973. Column (2) measures the difference between the change in export prices and domestic prices for each industry during the twelve months ending in December 1984. Column (3) is the analogous measure for the twelve months ending in December 1986. The sources are described in the text.

The results for the sample of German industries are mixed. First, it is noteworthy that roughly the same 
industries are concentrated in the two countries ${ }^{4}$ Second, it is encouraging that almost all industries cases of price increases during 1986, when the mark was appreciating relatively rapidly against the dollar and several of the weaker European currencies. The Spearman statistic for rank correlation between industry concentration and pass-through in 1984 is not significant at the $10 \%$ level; the rejection is based largely upon the behavior of the processed foodstuffs industry, which exhibited a relatively high degree of pass-through in that period. That industry's ability to raise export prices during a period when the mark was weak within the European Monetary System may have had something to do with the European Community's Common Agricultural Policy. Export price markdowns in 1986 shiw only a very weak correlation with industry concentration.

\section{CONCLUSION}

This note has presented a simple test of one of the implications of the theoretical literature on exchange rate pass-through. It has used a Spearman rank correlation test to show that export price marku.ps in Japanese industries were correlated with industrial concentration during the last year in which the yen and mark depreciated against the dollar. There was weaker evidence that German industries increased their export price markups during the same year. Even though most Japanese and German industries did cut their markups during 1986, the theory about the effects of industry concentration during an appreciation did not fare well at all.

It is striking that in the same industries there is a strong rank correlation between industrial concentration in the two countries. This is probably an indication that the technological considerations that give rise to concentrated industries in Germany are present in Japan as well. This factor may help exchange rate movements to serve as a ratchet on international prices, allowing world oligopolists in

${ }^{4}$ Indeed, the rank correlation between the two countries' measures of industrial concentration is significant at the $95 \%$ confidence level 
concentrated industries to raise export price markups during periods when their domestic currencies are weak. When exchange rate movements necessitate cutting export price markups, it seems that oligopolists find ways of maintaining world market share without having to lower their prices. This indicates that the asymmetric effects of flexible exchange rates on imperfectly competitive world markets may merit further study.

\section{REFERENCES}

Baldwin, Richard, 1988, Hysteresis in import prices: The beachhead effect, The American Economic Review 78, 773-785.

Bank of Japan, Research and statistics department, 1984 and 1986, Price Indices Monthly: Wholesale Price Indices, 59 and 61.

Bickel, Pet.er J. and Kjell A. Doksum, 1977, Mathematical statistics: Basic ideas and selected topics (Holden-Day, San Francisco, CA).

Caves, Richard E. and Masu Uekusa, 1976, Industrial organization in Japan (The Brookings Institution, Washington, DC).

Dornbusch, Rudiger, 1987, Exchange rates and prices. The American Economic Review 77,93-106.

Dunn, Robert M., Jr., 1970, Flexible exchange rates and oligopoly pricing: A study of Canadian markets, Journal of Political Economy 78, 140-151.

Feinberg, Robert M., 1986, The interaction of foreign exchange and market power effects on German domestic prices, The Journal of Industrial Economics XXXV, 61-79.

Fisher, Eric, 1989, A model of exchange rate pass-through, Journal of International Economics 26, 119137.

Germany, Monopolkommission, 1976, Mehr Wettbewerb ist moglich (Nomos-Verlagsgesellschaft, Baden-Baden). 
Germany, Statistisches Bundesamt, 1987, Preise und Preisindizes fOr gewerbliche Produkte (Erzeugerpreise), Reihe 2.

Germany. Statistisches Bundesamt, 1984 and 1987, Preise und Preisindizes fOr die Ein-und Ausfuhr, Reihe 8.

Japan, Fair Trade Conunission, 1973, Niho no sangyo shuchu [Industrial concentration in Japan 19631966] (Toyo Keiza Shinposha, Tokyo).

Japan, Statistics Bureau, 1983, Japn statistical yearbook: 1983 Prime Minister's Office, Tokyo).

Mann, Catherine L., 1986, Prices, profit margins, and exchange rates, Federal Reserve Bulletin 72, 366379.

Odagiri, Hiroyuki and Takashi Yamashita, 1987, Price mark-ups, market structure, and business fluctuations in Japanese manufacturing industries, The Journal of Industrial Economics XXXV, 317-331.

* The author would like to thank the Ubrary of Congress, whose staff in the section on Japanese acquisitions helped him find the relevant statistical materials. He would also like to thank Manfred Neumann, who directed his attention to the publications of the Monopolkomrnission. 